\title{
Kajian Model Hidrograf Akibat \\ Perubahan Tataguna Lahan dengan Menggunakan Data Lapangan DAS Batang Air Dingin
}

\section{Study of Hydrograph Assessment Model Due Changes in Land Use Using Batang Air Dingin Watershed Fields Data}

\author{
Elvi Roza Syofyan ${ }^{1)}$, Amrizal Saidi $^{2)},{\text { Bambang } \text { Istijono }^{3)} \& \text { Revalin Herdianto }}^{\text {() }}$ \\ 1)Jurusan Teknik Sipil Politeknik Negeri Padang Kampus Limau Manis Padang 25163 \\ Telp.0751-72590 Fax.0751-72576 Email: syofyan_er@yahoo.co.id \& \\ revalin.herdianto@gmail.com \\ 2) Jurusan Tanah/Prodi Agroekoteknologi Fakultas Pertanian Universitas Andalas Padang 25163 \\ Kampus Limau Manis Padang Email : amrizal.saidi@gmail.com \\ ${ }^{3)}$ Jurusan Teknik Sipil Fakultas Teknik Universitas Andalas Padang 25163 \\ Kampus Limau Manis Padang Email : bistijono1452@ yahoo.co.id
}

\begin{abstract}
Heavy rains on Monday, 21/3/2016, which flushed the city of Padang, West Sumatra, causing floods and submerged thousands of homes at local residents. This time called the flooding the worst experienced by the region in recent years. Head of Logistics Emergency and Disaster Management Agency said flooding in Padang city West Sumatra at this time was the worst, because it contributes to soak the areas that usually never flooded. The purpose of the study is to look at changes in land use and hydrograph models of Batang Air Dingin watershed using field data.

The results shows the change of land use of Batang Air Dingin Watershed can decreased 1.57\% from 2011 to 2015. It due to the opening of new land. While shrub rose rose $0.70 \%$, because was due of changes of forests that have not done processing. For an others using of the land the number increase $1.75 \%$. It due to changes of forests and shrubs into failure land.. As the runoff coefficient (C) does not occur any significant change that is from 0.443 into 0.445. Peak discharge calculated by the Nakayasu method $179.274 \mathrm{m3} / \mathrm{dt}$, was greater by Snyder method of $177.150 \mathrm{~m} 3 / \mathrm{dt}$ is caused no difference in the approach used.
\end{abstract}

Keywords: Hydrograph, Land Use, Watershed

\section{PENDAHULUAN}

DAS Batang Air Dingin terletak pada $0^{\circ} 48^{\prime}$ sampai dengan $0^{\circ} 56^{\prime}$ Lintang Selatan dan $100^{\circ} 21^{\prime}$ 'sampai dengan $100^{\circ} 33^{\prime}$ 'Bujur Timur, dengan ketinggian 0 sampai dengan 1.210 M dpl. Batang Air Dingin merupakan sungai utama pada DAS Batang Air Dingin, yang sumber airnya berasal dari beberapa anak sungai di wilayah hulu seperti Sungai Kapecong, Sungai Air Tiris, Sungai Latuang, Batang Sako dan Sungai Abu (Nursidah, 2012). Luas DTA bagian hulu DAS Batang Air Dingin sekitar 57.200 hektar $\left(57,200 \mathrm{Km}^{2}\right)$, meliputi kawasan konservasi, hutan lindung dan lahan milik masyarakat. DAS ini terutama di bagian hulunya didominasi oleh lahan yang memiliki kemiringan $25-40 \%$ yaitu sebesar 57,55\% (Nursidah, 2012).

Hujan deras hari senin tanggal 21/3/2016, yang mengguyur Kota Padang, Sumatera Barat, menyebabkan banjir dan merendam ribuan rumah warga setempat. Banjir kali ini disebut yang terparah dialami daerah itu dalam beberapa tahun terakhir.

Kepala Bidang Kedaruratan dan Logistik Badan Penanggulangan Bencana Daerah (BPBD) Sumbar menyebutkan banjir di Kota Padang saat ini merupakan yang terparah, karena ikut merendam daerah yang biasanya tidak pernah terkena banjir. Informasi yang dihimpun Bisnis/JIBI, banjir setidaknya merendam 
ribuan rumah warga di Kecamatan Nanggalo, Koto Tangah

Padang Selatan dan Padang Utara, Kota Padang, dengan kedalaman mencapai 1,5 meter.

Banjir terparah terjadi di Kecamatan Koto Tangah yang kedalamannya merata di sejumlah kelurahan, seperti Dadok Tunggul Hitam, Air Pacah, Padang Sarai, Bungo Pasang, Pasia Jambak, Lubuk Buaya, dan Tabing Banda Gadang dengan ketinggian banjir rerata 1 meter sampai 1,5 meter.

Di kawasan Ulak Karang, Padang Utara banjir berkisar $80 \mathrm{~cm}$ hingga 1 meter. Begitu juga di kawasan Padang Selatan dengan ketinggian banjir sekitar 1 meter. Sedangkan daerah lainnya di Kota Padang hanya diselimuti banjir kecil setinggi lutut.

Tujuan dari penelitian adalah untuk melihat perubahan tataguna lahan dan Model Hidrograf pada DAS Batang Air Dingin menggunakan data lapangan.

\section{Daerah Aliran Sungai}

DAS merupakan suatu kawasan yang dibatasi oleh batasan-batasan topografi secara alami merupakan wilayah hidrologi dengan sungai dan anak-anak sungai sebagai komponen utama untuk mengalirkan setiap air hujan, sedimen dan unsur lainnya pada sungai ke suatu pengeluaran (outlet) dan titik-titik pengukuran debit aliran, sedimen, dan kualitas air suatu sungai.

Menurut Arsyad (1989), DAS adalah sebagai satuan wilayah yang terletak diatas suatu titik pada suatu sungai yang oleh batas-batas topografi mengalirkan air yang jatuh diatasnya kedalam sungai yang sama dan mengalir melalui suatu titik yang sama pada sungai tersebut.

Menurut Sri-Harto (1993), DAS merupakan daerah tangkapan yang semua airnya mengalir kedalam suatu alur sungai, daerah ini umumnya dibatasi oleh batas topografi yang jelas dan ditetapkan berdasar aliran permukaan.

DAS merupakan suatu sistem alami dalam hidrologi dengan sungai sebagai komponen utama. Aliran sungai sangat dipengaruhi oleh karakteristik curah hujan dan kondisi biofisik DAS. Karakteristik biofisik mencakup geometri (ukuran, bentuk, kemiringan DAS), morfometri (ordo sungai, kerapatan jaringan sungai, rasio percabangan, rasio panjang), pedologi dan geologi, serta penutupan lahan (Liamas 1993). Diantara kelima ciri kondisi biofisik, tipe penutupan lahan merupakan satusatunya parameter yang dapat mengalami perubahan secara cepat dan memberikan pengaruhnya secara signifikan terhadap karakteristik debit (Kartiwa et al. 2004)

\section{Penggunaan Lahan}

Menurut Arsyad (1989), sifat-sifat lahan (land characteristics), merupakan suatu keadaan unsur-unsur yang dapat diukur, dan sifat lahan tersebut akan dapat menentukan dan mempengaruhi prilaku lahan seperti ketersediaan air, peredaran udara, perkembangan akar, kepekaan erosi, ketersediaan unsur hara dan sebagainya, sehingga prilaku lahan sangat menentukan pertumbuhan vegetasi yang disebut sebagai kualitas lahan.

Evaluasi lahan merupakan salah satu komponen penting dalam proses perencanaan penggunaan lahan (land use planning) yang hasilnya dapat memberikan alternatif penggunaan lahan dan batasbatas kemungkinan penggunaannya, serta tindakan pengelolaan yang diperlukan agar lahan dapat berfungsi secara lestari (FAO 1976).

Peran sistem penggunaan lahan pada suatu bentang lahan dapat dinilai dari sudut perubahan tingkat evapotranspirasi yang berhubungan dengan keberadaan pohon, laju infiltrasi tanah yang berhubungan dengan kondisi fisik tanah, dan laju drainase yang berhubungan dengan jaringan drainase (Noordwijk et al. 2004).

Peningkatan intensitas perubahan alih fungsi lahan membawa pengaruh negatif terhadap kondisi hidrologis DAS diantaranya meningkatnya debit puncak, fluktuasi debit antar musim, koefisien 
aliran permukaan, serta banjir dan kekeringan (Kartiwa et al. 2004).

Perubahan penggunaan lahan dengan memperluas permukaan kedap air menyebabkan berkurangnya infiltrasi, menurunkan pengisian air bawah tanah dan meningkatkan aliran permukaan. Peningkatan aliran permukaan akan mempengaruhi debit aliran pada suatu sungai.

\section{Model Hidrograf}

Hidrograf dapat digambarkan sebagai penyajian grafis antara salah satu unsur aliran dengan waktu (Harto, 1993). Sedangkan hidrograf limpasan didefinisikan sebagai grafik yang kontinyu yang menunjukkan sifat-sifat dari aliran sungai berkaitan dengan waktu normalnya diperoleh dari garis pencatatan kontinyu yang mengindikasikan debit dengan waktu (Viessman et. al., 1989).

Hidrograf memberikan gambaran mengenai berbagai kondisi (karakteristik) yang ada di DAS secara bersama-sama, sehingga apabila karakteristik DAS berubah maka akan menyebabkan perubahan bentuk hidrograf (Sosrodarsono dan Takeda 1983). Hidrograf juga menunjukkan tanggapan menyeluruh DAS terhadap masukan tertentu. Sesuai dengan sifat dan perilaku DAS yang bersangkutan, hidrograf aliran selalu berubah sesuai dengan besaran dan waktu terjadinya masukan (Harto 1993).

(Linsley et. al., 1982) menyatakan terdapat 3 komponen penyusun hidrograf, yaitu :

1. Aliran diatas tanah (overland flow/surface runoff), yaitu air yang dalam perjalanannya menuju saluran melalui permukaan tanah.

2. Aliran bawah permukaan (interflow/subsurface storm flow), ialah sebagian air yang memasuki permukaan tanah dan bergerak ke samping melauli lapisan atas tanah sampai saluran sungai. Kecepatan pergerakan aliran bawah permukaan ini lebih lambat dibandingkan dengan aliran permukaaan.

3. Aliran air tanah (groundwater flow) yang disebut sebagai aliran dasar.

Wilson (1990) mengemukakan bahwa mula-mula yang ada hanya aliran dasar yaitu aliran yang berasal dari tanah dan akuifer-akuifer yang berbatasan dengan sungai sang mengalir terus menerus secara perlahan-lahan sepanjang waktu. Segera setelah hujan mulai turun, terdapat suatu periode awal dari intersepsi dan infiltrasi sebelum setiap limpasan terukur mencapai aliran sungai/anak sungai dan selama periode turunnya hujan kehilangan tersebut akan terus berlangsung tetapi dalam jumlah yang semakin kecil. Apabila kehilangan awal telah terpenuhi, maka limpasan permukaan akan terjadi dan akan berlanjut terus hingga suatu nilai puncak yang terjadi pada waktu puncak. Kemudian limpasan permukaan akan turun sepanjang sisi turun (recession limb) sampai hilang sama sekali.

\section{Bentuk Hidrograf}

Bentuk hidrograf pada umumnya dapat sangat dipengaruhi oleh sifat hujan yang terjadi, akan tetapi juga dapat dipengaruhi oleh sifat DAS yang lain (Harto 1993, Viessman et. al., 1989). Seyhan (1977) mengemukakan bahwa hidrograf periode pendek terdiri atas cabang naik, puncak (maksimum) dan cabang turun. Sedangkan untuk hidrograf jangka panjang dibedakan menjadi 3 yaitu hidrograf bergigi, hidrograf halus dan hidrograf yang ditunjukkan oleh sungai-sungai besar (Ward 1967, dalam Seyhan 1977). Perbedaan antara jangka pendek dan jangka panjang tersebut tergantung pada panjang waktu dari tujuan pengamatan yang dilakukan (Kobatake, 2000). Seyhan (1977), Viessman et. al., (1989) dan Harto (1993) membagi hidrograf menjadi 3 bagian yaitu sisi naik (rising limb), puncak (crest) dan sisi resesi (recession limb). Oleh sebab itu bentuk hidrograf dapat ditandai dari tiga sifat pokoknya, 
yaitu waktu naik (time of rise), debit puncak (peak discharge) dan waktu dasar (base time). Waktu naik adalah waktu yang diukur dari saat hidrograf mulai naik sampai terjadinya debit puncak. Debit puncak (Qp) adalah debit maksimum yang terjadi dalam kejadian hujan tertentu. Waktu dasar ( $\mathrm{Tb})$ adalah waktu yang diukur saat hidrograf mulai naik sampai waktu dimana debit kembali pada suatu besaran yang ditetapkan (Harto, 1993).

Karakter kontribusi air tanah pada aliran banjir sangat berbeda dari limpasan permukaan, maka kontribusi air tanah harus dianalisis secara terpisah, dan oleh karenanya salah satu syarat utama dalam analisis hidrograf ialah memisahkan kedua hal tersebut (Wilson, 1990).

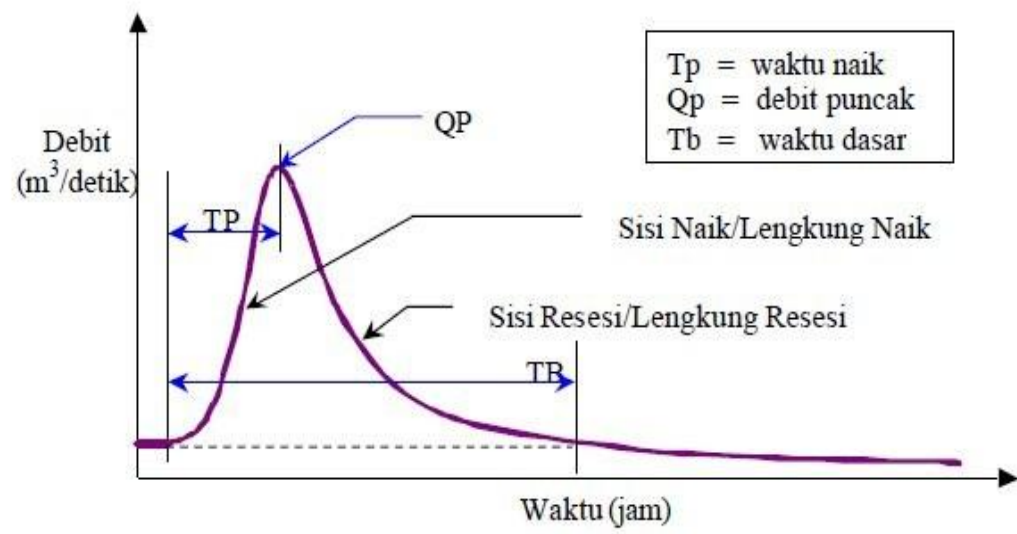

Gambar 1. Bentuk hidrograf

\section{Hidrograf Satuan Sintesis}

Hidrograf Satuan Sintetis adalah hidrograf yang di dasarkan atas sintetis parameter-parameter daerah aliran sungai (Sutapa, 2005). Seyhan (1977) mengemukakan bahwa beberapa parameter fisik DAS berperan dalam menentukan bentuk hidrograf satuan selain karakteristik hujan. Parameter fisik DAS tersebut adalah luas DAS, kemiringan, panjang sungai. Parameterparameter fisik DAS itulah yang akan dipergunakan untuk menetapkan besarnya hidrograf satuan dari DAS yang bersangkutan dengan metode hidrograf satuan sintesis.

Keuntungan dari penggunaan hidrograf sintesis adalah bisa mensintesasikan hidrograf dari DAS yang terukur dan menggunakannya untuk DAS yang tidak terukur (Seyhan, 1977). Kelemahan dari hidrograf satuan sintesis adalah karena persamaan hidrograf satuan sintesis dibuat secara empiris dengan data yang diperoleh pada tempat-tempat lokal, persamaan tersebut terbatas pada kawasan dengan kondisi geografis yang serupa dengan kawasan dimana persamaan tersebut diperoleh (Seyhan 1977, Harto 1993). Metode hidrograf satuan sintesis yang saat ini umum digunakan di Indonesia antara lain adalah metode Snyder - SCS, Nakayasu, GAMA-1.

\section{METODOLOGI}

\section{Data curah hujan}

Data Primer yang diperoleh dari Dinas PSDA Propinsi Sumatera Barat dari waktu pengukuran dari tanggal 21-3-2016 sampai dengan 22-3-2016, lokasi : Kantor Dinas PSDA Jalan Khatib Sulaiman. 
Tabel 1. Data Curah Hujan

\begin{tabular}{|c|c|c|c|}
\hline No & Tgl & Jam & Curah Hujan \\
\hline 1 & $3 / 21 / 2016$ & $12: 00: 03$ & 0 \\
\hline 2 & $3 / 21 / 2016$ & $13: 00: 03$ & 0 \\
\hline 3 & $3 / 21 / 2016$ & $14: 00: 03$ & 0 \\
\hline 4 & $3 / 21 / 2016$ & $15: 00: 03$ & 0 \\
\hline 5 & $3 / 21 / 2016$ & $16: 00: 03$ & 0 \\
\hline 6 & $3 / 21 / 2016$ & 17:00:03 & 0 \\
\hline 7 & $3 / 21 / 2016$ & 18:00:03 & 6 \\
\hline 8 & $3 / 21 / 2016$ & 19:00:03 & 10 \\
\hline 9 & $3 / 21 / 2016$ & 20:00:03 & 20 \\
\hline 10 & $3 / 21 / 2016$ & 21:00:03 & 5 \\
\hline 11 & $3 / 21 / 2016$ & 22:00:03 & 10 \\
\hline 12 & $3 / 21 / 2016$ & $23: 00: 03$ & 20 \\
\hline 13 & $3 / 22 / 2016$ & 0:00:03 & 70 \\
\hline 14 & $3 / 22 / 2016$ & 1:00:03 & 70 \\
\hline 15 & $3 / 22 / 2016$ & $2: 00: 02$ & 20 \\
\hline 16 & $3 / 22 / 2016$ & $3: 00: 02$ & 20 \\
\hline 17 & $3 / 22 / 2016$ & $4: 00: 03$ & 30 \\
\hline 18 & $3 / 22 / 2016$ & $5: 00: 03$ & 3 \\
\hline 19 & $3 / 22 / 2016$ & $6: 00: 02$ & 2 \\
\hline 20 & $3 / 22 / 2016$ & $7: 00: 03$ & 0 \\
\hline 21 & $3 / 22 / 2016$ & 8:00:03 & 0 \\
\hline 22 & $3 / 22 / 2016$ & 9:00:02 & 0 \\
\hline 23 & $3 / 22 / 2016$ & 10:00:03 & 0 \\
\hline 24 & $3 / 22 / 2016$ & 11:00:03 & 0 \\
\hline 25 & $3 / 22 / 2016$ & 12:00:02 & 5 \\
\hline 26 & $3 / 22 / 2016$ & $13: 00: 03$ & 2 \\
\hline 27 & $3 / 22 / 2016$ & 14:00:02 & 0 \\
\hline 28 & $3 / 22 / 2016$ & $15: 00: 03$ & 0 \\
\hline 29 & $3 / 22 / 2016$ & $16: 00: 03$ & 0 \\
\hline 30 & $3 / 22 / 2016$ & 17:00:02 & 0 \\
\hline 31 & $3 / 22 / 2016$ & 18:00:03 & 0 \\
\hline 32 & $3 / 22 / 2016$ & 19:00:03 & 0 \\
\hline 33 & $3 / 22 / 2016$ & 20:00:02 & 0 \\
\hline 34 & $3 / 22 / 2016$ & 21:00:03 & 0 \\
\hline 35 & $3 / 22 / 2016$ & $22: 00: 03$ & 0 \\
\hline 36 & $3 / 22 / 2016$ & $23: 00: 03$ & 0 \\
\hline
\end{tabular}

Data Perubahan Tutupan Lahan

Pola hubungan tinggi muka air terhadap waktu (hidrograf), potensi ini sangat tergantung dari perubahan tutupan lahan. Data tutupan Lahan Kota Padang dari
Tahun 2011 sampai 2015 dengan resolusi yang lebih tinggi. Data sekunder di validasi dengan survey lapangan menggunakan GPS. 


\section{Analisa Hidrologi}

Analisa hidrologi meliputi pengumpulan data sekunder curah hujan jam-jaman yang terjadi pada 21-3-2016 sampai dengan 223-2016. Data yang dikumpulkan berasal dari stasiun yang berada di dalam dan di sekitar DAS Air Dingin yaitu stasiun curah hujan Khatib sulaiman (Kantor Dinas PSDA). Dari data curah hujan maksimum terjadi, dilakukan analisis dengan hydrograf dengan metoda Nakayasu dan metode snyder.

\section{HASIL}

\section{Perubahan Tata Guna Lahan}

Hasil analisis penggunaan lahan DAS Batang Air Dingin tidak memperlihatkan perubahan penggunaanlahan yang signifikan. terutama pada; Hutan primer, hutan sekunder, hutan tanaman, perkebunan, semak belukar dan tanah terbuka. Apabila penggunaan lahan dibuat berdasarkan perubahan penggunaan lahan satu periode melebihi nilai 10 hektar maka, penggunaan lahan digolongkan pada 3 penggunaan lahan yaitu; hutan, semak belukar, dan penggunaan lain- lain dengan jumlah penggunaan lahan selama 4 periode adalah seperti Tabel 2 .

Tabel 2. Data Pengunaan Lahan dan Koefisien Limpasan

\begin{tabular}{|c|c|c|c|c|c|c|c|c|c|c|c|c|c|c|c|}
\hline \multirow{2}{*}{$\begin{array}{l}\text { Jenis Penggunaan } \\
\text { Lahan }\end{array}$} & \multicolumn{3}{|c|}{ Tahun 2011} & \multicolumn{3}{|c|}{ Tahun 2012} & \multicolumn{3}{|c|}{ Tahun 2013} & \multicolumn{3}{|c|}{ Tahun 2014} & \multicolumn{3}{|c|}{ Tahun 2015} \\
\hline & $\mathrm{Km} 2$ & $\%$ & C & $\mathrm{Km} 2$ & $\%$ & C & $\mathrm{Km} 2$ & $\%$ & C & $\mathrm{Km} 2$ & $\%$ & C & Km2 & $\%$ & C \\
\hline Hutan & 26.44 & 46.22 & 0.400 & 26.44 & 46.22 & 0.400 & 26.44 & 46.22 & 0.400 & 25.84 & 45.17 & 0.400 & 25.54 & 44.65 & 0.400 \\
\hline Semak Belukar & 12.24 & 21.40 & 0.450 & 12.02 & 21.01 & 0.450 & 11.74 & 20.52 & 0.450 & 12.04 & 21.05 & 0.450 & 12.14 & 21.22 & 0.450 \\
\hline Penggunaan Lain-lain & 18.52 & 32.38 & 0.500 & 18.74 & 32.76 & 0.500 & 19.02 & 33.25 & 0.500 & 19.32 & 33.78 & 0.500 & 19.52 & 34.13 & 0.500 \\
\hline Total / Rata-rata & 57.20 & 100 & 0.443 & 57.20 & 100 & 0.443 & 57.20 & 100 & 0.444 & 57.20 & 100 & 0.444 & 57.20 & 100 & 0.445 \\
\hline
\end{tabular}

Hasil perhitungan

Penggunaan lahan lain terdiri dari : Pemukiman, tanah terbuka, pertanian lahan kering, pertanian lahan kering campur semak, dan sawah

Dari Tabel 2. jumlah hutan pada DAS Batang Air Dingin terjadi penurunan sedikit 1,57\% dari tahun 2012 sampai 2015 disebabkan karena terjadinya pembukaan lahan baru. Sedangkan semak belukar meningkat meningkat $0,70 \%$, ini disebabkan karena karena adanya perubahan hutan yang belum dilakukan pengolahan. Untuk penggunaan lain-lain terjadi peningkatan $1,75 \%$ ini disebabkan karena adanya perubahan hutan dan semak belukar menjadi pertanian lahan kering, tanah terbuka serta pemukiman. Sedangkan untuk Koefisien Limpasan ( C ) terjadi perubahan dari 0,443 menjadi 0,445 .

\section{PEMBAHASAN}

\section{Metode Snyder}

Persamaan umum hidrograf satuan sintetik adalah sebagai berikut :

$$
Q p=\frac{0,275 \cdot C p \cdot A}{T p}
$$

Parameter-parameter perhitungan yang diperlukan adalah sebagai berikut

a). Karakteristik DAS, meliputi :

Luas daerah aliran sungai (A)

$$
=57.20 \mathrm{Km}^{2}
$$

Panjang sungai utama (L)

$$
=26,55 \mathrm{Km}
$$

Panjang sungai dari outlet ketitik berat

DAS $=19.55 \mathrm{~km}$

Koefisien waktu $\left(\mathrm{C}_{\mathrm{t}}\right) \quad=2.20$

Koefisien puncak $\left(\mathrm{C}_{\mathrm{p}}\right)=1.20$

Koefisien nilai $\mathrm{n} \quad=0.3$

b). Parameter-parameter hidrograf

Time Lag $\left(t_{p}\right)$ 


$$
\begin{aligned}
\mathrm{tP} & =0,75(\mathrm{~L} x \mathrm{LC}) \cdot \mathrm{n} \\
& =0,75 \cdot(26,55 \cdot 19,55) \cdot 0,3 \\
& =14,354 \mathrm{jam}
\end{aligned}
$$

Lama curah hujan efektif

te $=\mathrm{tP} / 5.5=14,354 / 5,5=2,610$ jam

te $>\operatorname{tr}=1$ jam, maka $\mathrm{TP}=\mathrm{tP}+0.25$

$$
\text { (te }- \text { tr) }
$$

te $<\operatorname{tr}=1$ jam, maka $\mathrm{Tp}=\mathrm{tP}+0.5 \mathrm{tr}$

maka: $\mathrm{Tp}=14,354+0.25$.

Debit Puncak $\left(\mathrm{Q}_{\mathrm{p}}\right)$

$$
\begin{aligned}
& (2,610-1,000) \\
= & 14,757 \text { jam }
\end{aligned}
$$

$$
\begin{aligned}
Q p & =\frac{0,275 \cdot C p \cdot A}{T p} \\
& =\frac{0,275 \cdot 1,20 \cdot 57,20}{14,757} \\
& =1,279 \mathrm{~m} 3 / \mathrm{detik} / \mathrm{mm}
\end{aligned}
$$

c). Metode Alexeyev

$$
\begin{aligned}
& \lambda=\frac{(Q p \cdot T p)}{(h \cdot A)} \\
& =\frac{(1,279 \cdot 14,757)}{(1,0 \cdot 57,20)}=0,321
\end{aligned}
$$$$
a=1,32 \cdot \lambda+0,15 \cdot \lambda+0,045
$$$$
=0,517
$$$$
x=\frac{t}{T p}=\frac{2}{14,757}=0,136
$$

$$
\begin{aligned}
y & =10^{-a \cdot \frac{(1-x)^{2}}{x}} \\
& =10^{-0,517 \cdot \frac{(1-2)^{2}}{2}} \\
& =0,001 \\
\mathrm{Q} & =\mathrm{y} \cdot \mathrm{Qp} \\
& =0,001 \cdot 1,279 \\
& =0,001 \mathrm{~m} 3 / \text { detik } / \mathrm{mm}
\end{aligned}
$$

Tabel 3. Rekapitulasi hasil perhitungan Hidrograf Metode Snyder

\begin{tabular}{ccccccccc}
\hline $\begin{array}{c}\text { Waktu } \\
\text { (jam) }\end{array}$ & $\mathrm{x}$ & $\mathrm{y}$ & $\mathrm{Q}$ & $\begin{array}{c}\mathrm{h}=70 \\
\mathrm{~mm}\end{array}$ & $\begin{array}{c}\mathrm{h}=20 \\
\mathrm{~mm}\end{array}$ & $\begin{array}{c}\mathrm{h}=20 \\
\mathrm{~mm}\end{array}$ & $\begin{array}{c}\mathrm{h}=30 \\
\mathrm{~mm}\end{array}$ & $\begin{array}{c}\mathrm{Q} \text { total } \\
(\mathrm{m} 3 / \mathrm{dt})\end{array}$ \\
\hline 1 & 0 & 0 & 0 & 0 & & & & 0 \\
2 & 0.136 & 0.001 & 0.001 & 0.103 & 0 & & & 0.103 \\
3 & 0.203 & 0.022 & 0.028 & 1.936 & 0.029 & 0 & & 1.965 \\
4 & 0.271 & 0.090 & 0.115 & 8.065 & 0.553 & 0.029 & 0 & 8.647 \\
5 & 0.339 & 0.205 & 0.262 & 18.363 & 2.304 & 0.553 & 0.044 & 21.264 \\
6 & 0.407 & 0.345 & 0.442 & 30.912 & 5.247 & 2.304 & 0.830 & 39.293 \\
7 & 0.474 & 0.489 & 0.626 & 43.790 & 8.832 & 5.247 & 3.456 & 61.324 \\
8 & 0.542 & 0.622 & 0.796 & 55.689 & 12.511 & 8.832 & 7.870 & 84.902 \\
9 & 0.610 & 0.736 & 0.942 & 65.907 & 15.911 & 12.511 & 13.248 & 107.577 \\
10 & 0.678 & 0.828 & 1.060 & 74.171 & 18.831 & 15.911 & 18.767 & 127.680 \\
11 & 0.745 & 0.899 & 1.150 & 80.471 & 21.192 & 18.831 & 23.867 & 144.360 \\
12 & 0.813 & 0.949 & 1.213 & 84.942 & 22.992 & 21.192 & 28.246 & 157.371 \\
13 & 0.881 & 0.980 & 1.254 & 87.787 & 24.269 & 22.992 & 31.788 & 166.836 \\
14 & 0.949 & 0.997 & 1.275 & 89.235 & 25.082 & 24.269 & 34.488 & 173.074 \\
15 & 1.016 & 1.000 & 1.279 & 89.510 & 25.496 & 25.082 & 36.404 & 176.491 \\
16 & 1.084 & 0.992 & 1.269 & 88.822 & 25.574 & 25.496 & 37.623 & 177.515
\end{tabular}




$\begin{array}{lllllllll}17 & 1.152 & 0.976 & 1.248 & 87.361 & 25.378 & 25.574 & 38.243 & 176.556 \\ 18 & 1.220 & 0.953 & 1.218 & 85.290 & 24.960 & 25.378 & 38.361 & 173.989 \\ 19 & 1.288 & 0.924 & 1.182 & 82.750 & 24.368 & 24.960 & 38.067 & 170.145 \\ 20 & 1.355 & 0.892 & 1.141 & 79.862 & 23.643 & 24.368 & 37.440 & 165.313 \\ 21 & 1.423 & 0.857 & 1.096 & 76.725 & 22.818 & 23.643 & 36.553 & 159.738 \\ 22 & 1.491 & 0.820 & 1.049 & 73.423 & 21.921 & 22.818 & 35.464 & 153.626 \\ 23 & 1.559 & 0.782 & 1.000 & 70.024 & 20.978 & 21.921 & 34.226 & 147.150 \\ 24 & 1.626 & 0.744 & 0.951 & 66.583 & 20.007 & 20.978 & 32.882 & 140.450 \\ 25 & & & & & 19.024 & 20.007 & 31.467 & 70.498 \\ 26 & & & & & & 19.024 & 30.010 & 49.034 \\ 27 & & & & & & & 28.536 & 28.536\end{array}$

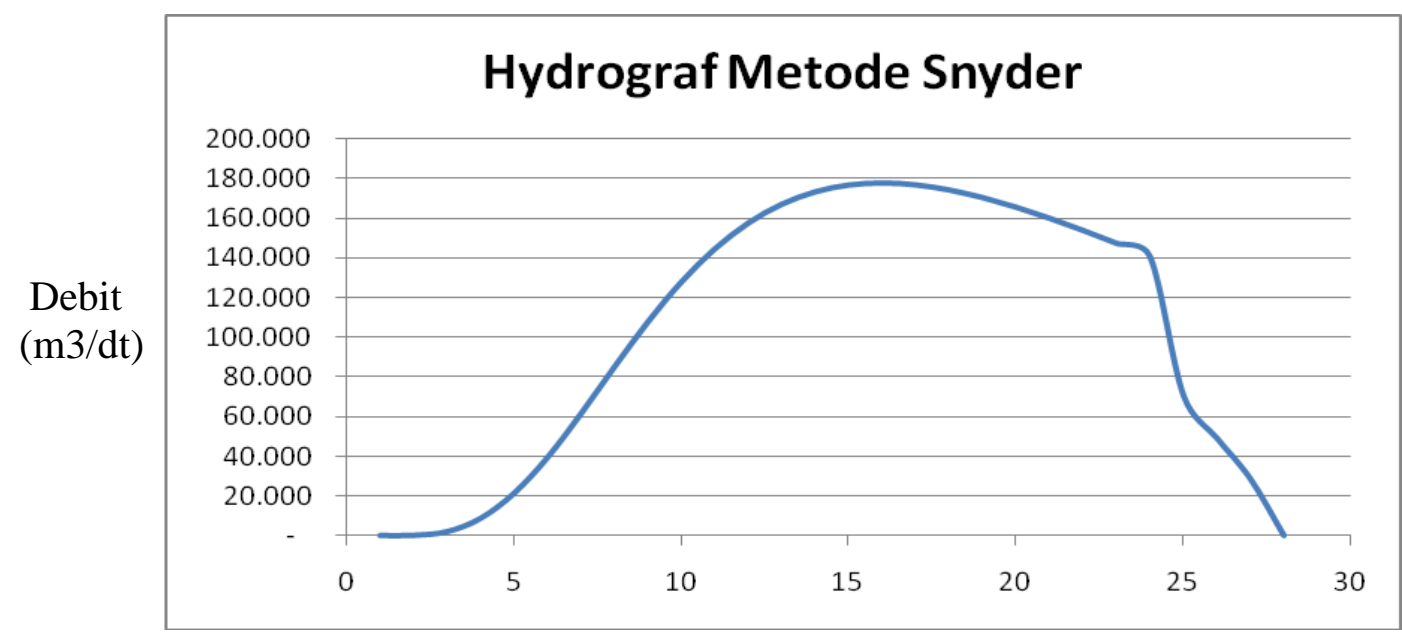

Waktu tP dan Tp (jam)

Gambar 2. Hydrograf Metode Snyder

Dari gambar 2 terlihat debit puncak $177,150 \mathrm{~m}^{3} / \mathrm{dt}$ dengan waktu menjelang puncak $\mathrm{Tp}=14,757$ jam sedangkan waktu dasarnya adalah 27,000 jam.

\section{Metode Nakayasu}

Persamaan umum hidrograf satuan sintetik adalah sebagai berikut :

$$
Q p=\frac{C \cdot A \cdot R o}{3,6 \cdot(0,3 \cdot T p+0,3)}
$$

a). Karakteristik DAS, meliputi :

Luas daerah aliran sungai (A)

$$
=57.20 \mathrm{Km}^{2}
$$

Panjang sungai utama (L)

$$
=26,55 \mathrm{Km}
$$

Koefisien karakteristik fisik DAS $(\alpha)$ $=1,0$

Hujan netto satuan $\quad=1,0 \mathrm{~mm} / \mathrm{jam}$

Koefisien puncak $\left(\mathrm{C}_{\mathrm{p}}\right)=1.20$

Run off Coefficient Koefisien (C) $=0.445$

b). Parameter-parameter hidrograf :

Dengan L $<15 \mathrm{Km}$, maka

$$
\mathrm{Tg}=0,21 \times \mathrm{L}^{0,7}
$$

$\mathrm{L}>15 \mathrm{Km}$, maka

$\mathrm{Tg}=0,40 \times 0,0058 . \mathrm{L}$ 
Maka :

$$
\begin{aligned}
\operatorname{Tg} & =0,40 \times 0,0058.26,55 \\
& =1,940 \mathrm{jam}
\end{aligned}
$$

Satuan waktu hujan (Tr)

$$
\begin{aligned}
\operatorname{Tr} & =0,75 \cdot \mathrm{Tg} \\
& =0,75 \cdot 1,940=1,455 \mathrm{jam}
\end{aligned}
$$

Tenggang waktu (Tp)

$$
T p=T g+0,8 . T r
$$$$
=1,940+0,8.1,455=3,104 \text { jam }
$$

Waktu penurunan debit, dari debit puncak sampai dengan menjadi 0,3 Qmaks $\left(\mathrm{T}_{0,3}\right)$.

$$
\begin{aligned}
T_{0,3} & =\alpha \cdot \mathrm{Tg} \\
& =1 \cdot 1,940=1,940 \mathrm{jam}
\end{aligned}
$$

Debit puncak

$$
\begin{aligned}
Q p & =\frac{0,455 \cdot 57,20 \cdot 1,0}{3,6 \cdot(0,3 \cdot 3,104+1,940)} \\
& =2,463 \mathrm{~m} 3 / \mathrm{detik} / \mathrm{mm}
\end{aligned}
$$

c). Durasi Waktu yang diperlukan.

Waktu lengkung naik $(0 \leq \mathrm{t} \leq \mathrm{Tp})$ satuan yang digunakan adalah :

$$
Q a=Q p \cdot\left(\frac{1}{T p}\right)^{2,4}
$$

Waktu lengkung turun $1(\mathrm{Tp} \leq \mathrm{t} \leq \mathrm{Tp}+$ $\mathrm{T}_{0,3}$ ) Persamaan Lengkung hidrograf unit satuan yang digunakan adalah :

$$
Q a=Q p .0,3 .\left(\frac{t-T p}{T_{0,3}}\right)
$$

\begin{tabular}{|c|c|c|}
\hline $\mathrm{T}$ (jam) & $U(t, 1)$ & Keterangan \\
\hline 0 & 0 & \multirow{7}{*}{ 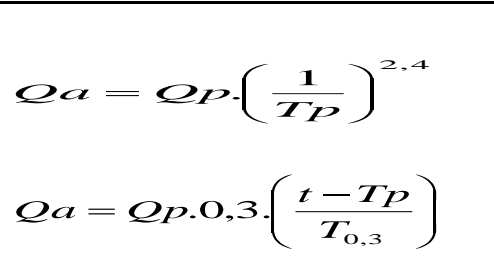 } \\
\hline 1 & 0.163 & \\
\hline 2 & 0.858 & \\
\hline 3 & 2.270 & \\
\hline 4 & 2.463 & \\
\hline 5 & 2.463 & \\
\hline 6 & 2.463 & \\
\hline 7 & 2.463 & \multirow{2}{*}{$Q a=Q p \cdot 0,3 \cdot\left(\frac{t-T_{P}+0,5 . T_{0,3}}{1,5 . T_{0,3}}\right)$} \\
\hline 8 & 2.463 & \\
\hline 9 & 2.463 & \multirow{16}{*}{$Q a=Q p \cdot 0,3 \cdot\left(\frac{t-T p+1,5 . T_{0,3}}{2,0 . T_{0,3}}\right)$} \\
\hline 10 & 2.463 & \\
\hline 11 & 2.463 & \\
\hline 12 & 2.463 & \\
\hline 13 & 2.463 & \\
\hline 14 & 2.463 & \\
\hline 15 & 2.463 & \\
\hline 16 & 2.463 & \\
\hline 17 & 2.463 & \\
\hline 18 & 2.463 & \\
\hline 19 & 2.463 & \\
\hline 20 & 2.463 & \\
\hline 21 & 2.463 & \\
\hline 22 & 2.463 & \\
\hline 23 & 2.463 & \\
\hline 24 & 2.463 & \\
\hline
\end{tabular}

Waktu lengkung turun $2\left(\mathrm{Tp}+\mathrm{T}_{0,3} \leq\right.$ $\left.\mathrm{t} \leq \mathrm{Tp}+1,5 \mathrm{~T}_{0,3}\right)$ Persamaan lengkung hidrograf unit satuan yang digunakan adalah :

$$
Q a=Q p .0,3 .\left(\frac{t-T p+0,5 \cdot T_{0,3}}{1,5 . T_{0,3}}\right)
$$

Waktu lengkung turun $3(\mathrm{t} \geq \mathrm{Tp}+1,5$ $\mathrm{T}_{0,3}$ ) Persamaan lengkung hidrograf unit satuan yang digunakan adalah :

$Q a=Q p .0,3 .\left(\frac{t-T p+1,5 . T_{0,3}}{2,0 . T_{0,3}}\right)$

Tabel 4. Tabulasi Perhitungan Hidrograf Metode Nakayasu 
Tabel 5. Rakapitulasi Hasil Perhitungan Hidrograf Metode Nakayasu

\begin{tabular}{ccccccccc}
\hline $\begin{array}{c}\mathrm{T} \\
(\mathrm{jam})\end{array}$ & $\mathrm{U}(\mathrm{t}, 1)$ & $\mathrm{Q}$ & $\mathrm{h}=70 \mathrm{~mm}$ & $\mathrm{~h}=20 \mathrm{~mm}$ & $\mathrm{~h}=20 \mathrm{~mm}$ & $\mathrm{~h}=30 \mathrm{~mm}$ & $\begin{array}{c}\text { Q total } \\
(\mathrm{m} 3 / \mathrm{dt})\end{array}$ \\
\hline 0 & - & - & - & - & - & - & - \\
1 & 0.163 & 0.16 & 11.375 & - & - & - & 11.375 \\
2 & 0.858 & 0.86 & 60.038 & 3.250 & - & - & 63.288 \\
3 & 2.270 & 2.27 & 158.870 & 17.154 & 3.25 & - & 179.274 \\
4 & 1.412 & 1.41 & 98.846 & 45.392 & 17.15 & 4.875 & 166.267 \\
5 & 0.759 & 0.76 & 53.140 & 28.242 & 45.39 & 25.730 & 152.504 \\
6 & 0.408 & 0.41 & 28.568 & 15.183 & 28.24 & 68.087 & 140.080 \\
7 & 0.007 & 0.01 & 0.475 & 8.162 & 15.18 & 42.363 & 66.183 \\
8 & 0.002 & 0.00 & 0.142 & 0.136 & 8.16 & 22.774 & 31.215 \\
9 & 0.001 & 0.00 & 0.058 & 0.041 & 0.14 & 12.244 & 12.478 \\
10 & 0.000 & 0.00 & 0.017 & 0.016 & 0.04 & 0.203 & 0.278 \\
11 & 0.000 & 0.00 & 0.005 & 0.005 & 0.02 & 0.061 & 0.088 \\
12 & 0.000 & 0.00 & 0.002 & 0.001 & 0.00 & 0.025 & 0.033 \\
13 & 0.000 & 0.00 & 0.000 & 0.000 & 0.00 & 0.007 & 0.010 \\
14 & 0.000 & 0.00 & 0.000 & 0.000 & 0.00 & 0.002 & 0.003 \\
15 & 0.000 & 0.00 & 0.000 & 0.000 & 0.00 & 0.001 & 0.001 \\
16 & 0.000 & 0.00 & 0.000 & 0.000 & 0.00 & 0.000 & 0.000 \\
17 & 0.000 & 0.00 & 0.000 & 0.000 & 0.00 & 0.000 & 0.000 \\
18 & 0.000 & 0.00 & 0.000 & 0.000 & 0.00 & 0.000 & 0.000 \\
19 & 0.000 & 0.00 & 0.000 & 0.000 & 0.00 & 0.000 & 0.000 \\
20 & 0.000 & 0.00 & 0.000 & 0.000 & 0.00 & 0.000 & 0.000 \\
21 & 0.000 & 0.00 & 0.000 & 0.000 & 0.00 & 0.000 & 0.000 \\
22 & 0.000 & 0.00 & 0.000 & 0.000 & 0.00 & 0.000 & 0.000 \\
23 & 0.000 & 0.00 & 0.000 & 0.000 & 0.00 & 0.000 & 0.000 \\
24 & 0.000 & 0.00 & 0.000 & 0.000 & 0.00 & 0.000 & 0.000
\end{tabular}

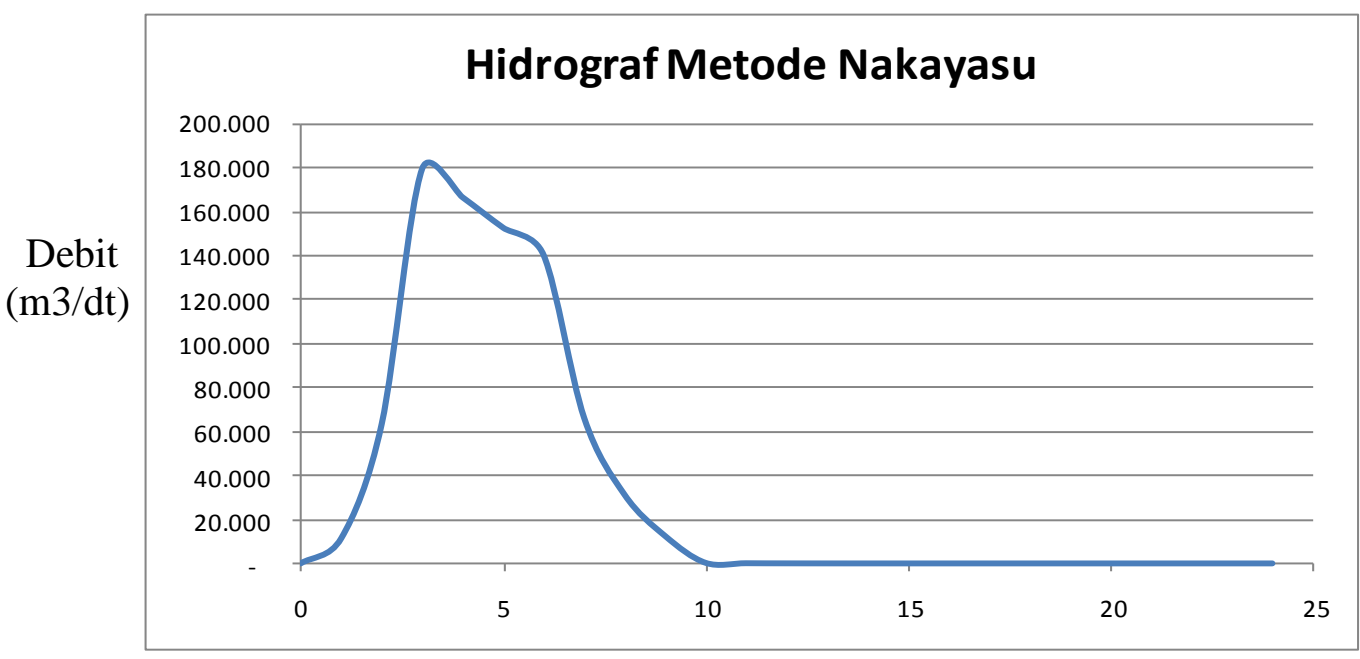

Waktu tP dan Tp (jam)

Gambar 3. Hydrograf Metode Nakayasu

Dari gambar 3 terlihat debit puncak $179,274 \mathrm{~m}^{3} / \mathrm{dt}$ dengan waktu menjelang puncak $\mathrm{Tp}=3,104$ jam sedangkan waktu dasarnya adalah 24,000 jam.

\section{SIMPULAN}

Penggunaan Lahan DAS Batang Air Dingin terjadi penurunan sedikit $1,57 \%$ dari tahun 2011 sampai 2015 disebabkan karena terjadinya pembukaan lahan baru. Sedangkan semak belukar meningkat 
meningkat 0,70 \%, ini disebabkan karena karena adanya perubahan hutan yang belum dilakukan pengolahan. Untuk penggunaan lain-lain terjadi peningkatan $1,75 \%$ ini disebabkan karena adanya perubahan hutan dan semak belukar menjadi pertanian lahan kering, tanah terbuka serta pemukiman. Sedangkan untuk Koefisien Limpasan ( C ) tidak terjadi perubahan yang signifikan yaitu dari 0,443 menjadi 0,445 .

Dari hasil pembahasan terlihat bahwa debit puncak yang dihitung dengan Metode Nakayasu 179,274 $\mathrm{m}^{3} / \mathrm{dt}$ lebih besar hasilnya dengan cara Metode Snyder $177,150 \mathrm{~m}^{3} / \mathrm{dt}$ ini disebabkan ada perbedaan pendekatan yang digunakan.

\section{SARAN}

Untuk keperlukan disain bangunan air (bendung), kebutuhan air untuk irigasi serta kebutuhan air minum Metode Nakayasu bisa direkomendasikan untuk dipakai.

\section{DAFTAR PUSTAKA}

Agus, I. 2007. Modifikasi Persamaan Hidrograf Satuan Sintesis Metoda Nakayasu Terhadap Hidrograf Satuan Observasi DAS Ciliwung Hulu. Rekayasa Sipil Volume III, No. 2, Oktober 2007. ISSN : 1858 - 3695.

Asdak C. 2002. Hidrologi dan Pengelolaan Daerah Aliran Sungai. Gadjah Mada university Press. Yogyakarta.

Furey PR dan Gupta VK., 2001, A Physically Based Filter For Separating Base Flow From Streamflow Time Series, Water Resources Research, Vol. 37, No. 11, Hal. 2709-2722, November 2001, University of Colorado, USA.

Harto, S. 1993 Hidrograf Satuan Sintetik Gamma I, Departemen Pekerjaan Umum. Yogyakarta.

Harto, S. 2000. Some Typical Cathment Parameter and Flow Component of Rivers on The Island of Java. Forum Teknik jilid 24 3:358-370.
Harto, S. 2000. Hidrologi : Teori, Masalah, Penyelesaian. Yogyakarta : Nafiri Offset.

Herdianto, R., Elvi Roza Syofyan, Aguskamar. Pemanfaatan Informasi Topografi dan Indeks Vegetasi untuk Studi Dinamika Proses Hidrologi Daerah Aliran. Jurnal Ilmiah POLI REKAYASA. Volume 8 Nomor 2, April 2013. ISSN : 1858-3709

Herdianto, R., Paik, K., Smettem, K., dan Coles., N. 2010. "Coupling vegetation index and terrain information for better representation of spatial and temporal dynamics of hydrological processes". Proceedings of 8 th International Symposium on Ecohydraulics. Seoul, September 2010. In CDROM.

Kurniawan, E. 2009, Analisis Debit Dan Muka Air Banjir Sungai Simpang Aur-Lemau Dengan Adanya PLTA Musi Kabupaten Bengkulu Utara. Universitas Indonesia. Skripsi. DKI Jakarta.

Kusumastuti, DI, Jowowinarno, D. 2012. Time Step Issue in Unit Hydrograph for Improving Runoff Prediction in Small Catchments. Journal of Water Resources and Protection, 2012, 4, $686-693$.

Mafriyal, Elvi Roza Syofyan. Pengelolaan dan Pemeliharaan Sungai dalam Rangka Pengembalian Sungai Kefungsi Aslinya. Bulletin Ilmiah EKASAKTI. Vol. XX No.1 Januari 2011 No.ISSN : 08754-8099.

Nursidah. 2012. "Pengembangan Institusi Untuk Membangun Kemandirian Dalam Pengelolaan Daerah Aliran Sungai Terpadu (Studi Kasus Pada Satuan Wilayah Pengelolaan Daerah Aliran Sungai Arau Sumatera Barat)". Disertasi. IPB. Hal. 80.

Pandey A, Chowdary V.M., Mal B.C. dan Dabral P.P., 2003, Estimation of runoff for agricultural 
watershed using SCS Curve Number and Geographic Information System, MAP India Conference, Department of Agricultural Engineering India.

Roza Syofyan, E., Aguskamar. Peranan Masyarakat dalam Pencegahan dan Penanggulangan Pencemaran Sungai. Jurnal Ilmiah POLI REKAYASA. Volume 8 Nomor 2, April 2013. ISSN : 1858-3709

Rapar Sharon Marthina Esther, Tiny Mananoma, Eveline M. W, Alex. B. Analisis Debit Limantara. Jurnal Sipil
Statik. Vol 2 No. 1, Januari 2014. ISSN : 2337-6732

Smadi M., 1998, Incorporating Spatial and Temporal Variation of Watershed Response in a Gis-Based Hydrologic Model, Tesis, Virginia Polytechnic Institute and State University.

United States Department of Agriculture, 1986, Urban Hydrology for Small Watersheds TR- 55, Washington.

USDA NRCS, 2005, National Engineering Handbook Section 4: Hydrology, Washington, DC, U.S.A. 